Article

\title{
Does Sustainability Affect Real Estate Market Values? Empirical Evidence from the Office Buildings Market in Milan (Italy)
}

\author{
Alessia Mangialardo ${ }^{1, *}$, Ezio Micelli ${ }^{1}$ (D) and Federica Saccani $^{2}$ \\ 1 Department of Architecture and Arts, IUAV University of Venice, 2206I-30123 Dorsoduro, Italy; \\ micelli@iuav.it \\ 2 Building Consultancy \& Sustainability, CBRE, Piazza degli Affari 2, 20123 Milan, Italy; \\ federica.saccani@cbre.com \\ * Correspondence: amangialardo@iuav.it
}

Received: 30 October 2018; Accepted: 14 December 2018; Published: 20 December 2018

\begin{abstract}
The construction industry is the world's largest consumer of energy and producer of greenhouse gases. For this reason, there is a broad debate on how to make the built environment more sustainable. Although the positive externalities of energy-efficient retrofitting and new construction are known, the economic effects that green building has on the real estate sector in Italy are less evident. The aim of this paper is to analyze the Italian real estate market to investigate if, and to what extent, demand appreciates the supply of green real estate assets. The research focused on the analysis of 55 development projects of office buildings (with and without environmental certification) located in Milan, at present the most dynamic and flourishing real estate market in Italy. Through these case studies the authors investigated the premium price that is generated in certified real estate development projects. The results highlight a premium price, especially for high levels of sustainability. Similarly, the rate of absorption of certified assets reflects a preference for green properties, which are absorbed by the real estate market in less than half of the time foreseen for real estate without an environmental certification.
\end{abstract}

Keywords: green buildings; sustainability; construction industry; LEED certification; real estate innovation

\section{Introduction}

The construction sector is the world's largest consumer of energy and a producer of greenhouse gases [1-3]. Recently, the Intergovernmental Panel on Climate Change-IPCC—has issued an alarm in its special report, pointing out the urgent need to step up actions to combat global warming. In this report, the IPCC calls on the most energy-intensive sectors including industry, transport, and construction to reduce global carbon dioxide emissions by $45 \%$ by 2030 compared to 2010 levels, and the zeroing of net emissions by 2050 [1].

According to the Triple Bottom Line (TBL) theory, to guarantee sustainable development of the built environment it is necessary to consider three elements: economy, environment, and society. Sustainability is at the heart of a process that evaluates not only the natural environment, but also the economic and social aspects [4]. Renewal or new construction operations must therefore include interventions that aim to achieve maximum environmental sustainability while ensuring the highest economic value and greater well-being of individuals [5-8].

The aim of this paper is to analyze the real estate market to verify if, and to what extent, demand appreciates supply of green real estate assets and to assess the eventual premium price that is generated in sustainable real estate development projects. We focused our research in Milan, at present the 
most dynamic and flourishing Italian real estate market. To investigate the level of appreciation of green buildings in Italy, it was decided to analyze the specific real estate segment of office buildings. The hypothesis is the following: this segment has always been a forerunner of future trends in the real estate industry because national and international players interact putting into evidence innovation trends in the industry.

How is it possible to define a building as "green"? The environmental certification protocols were created for this purpose, with the aim of defining criteria and methodology that evaluate their level of sustainability. Such certifications offer to consumers and investors a basis for comparison between alternatives investments or rents $[9,10]$. A score is assigned based on the achievement of certain objectives of excellence in comparison with standard performance. Unfortunately, at present, there is not a global rating system able to measure the level of sustainability in buildings, but each country uses its own protocol of certification with the consequence that comparing buildings rated through different certification may determine different levels of sustainability [11]. Generally, environmental certifications aim to reduce the level of information asymmetry between the construction sector and buildings owners and users [12].

The paper is divided into five sections. In the first we present the main general issues concerning sustainability and market values. In the second, using data from CBRE [13] and Green Business Certification Italy (GBCI) [14], we focused on the analysis of 55 recent real estate development projects. A large fraction of these green buildings has been awarded with the LEED certification while some of them were not. The third part analyzes the data of the sample by means of multivariate statistics. The fourth part interprets the results, while in the fifth part we present the conclusions.

\section{The Development of Green Buildings in Italy and in the World}

A long-term approach to preserve the environment can be pursued by making buildings more sustainable. European Union, through the Energy Performance of Buildings Directive 2002/91/EC, requires the energy consumption of each building to be specified through different levels of energy sustainability, although there is no obligation to make more "green" existing buildings. On the contrary, the European Directive 2018/844/UE regulates that buildings constructed from the end of 2020 must have high standards of reduction of energy consumption and must be primarily powered by renewable sources.

Environmental certification protocols have been developed to overcome information asymmetries to provide reliable and internationally valid label concerning buildings sustainability. Simple and affordable information is then provided to investors and tenants with all its sustainability characteristics [10,11].

There are various environmental certifications of buildings around the world. In the USA, the most widespread type of certification is Leadership in Energy and Environmental Design (LEED): it was adopted by firms to homogeneously assess their real estate portfolio and it has become the most used certification protocol worldwide. Australia adopted the Green Star System and Japan the Comprehensive Assessment System for Building Environmental Efficiency (CASBEE). In Canada there is the Green Globe System. In Europe, several certification protocols compete: in UK and in Netherlands Building Research Establishment Environmental Assessment Method (BREEAM) was widely adopted, Deutsche Gesellschaft Nachhaltiges Bauen (DGNB) is dominant in Germany, France implemented Haute Qualité Environmentale (HQE) and in Switzerland Minergie is a important standard.

In Italy, in addition to LEED and BREEAM certifications, adopted in particular for office and commercial buildings, other protocols are employed for residential buildings. CasaClima and SBTool protocols are widely used for residential developments while for social housing projects the Protocollo per la Trasparenza l'Aggiornamento e la Certificazione degli Appalti (ITACA) is the most common standard. Moreover, for properties for sale, it is mandatory to present an energy certificate attesting the average energy consumption associated with a synthetic level of quality performance [11]. 
For the purpose of this research, we decided to investigate LEED-certified buildings, which represent the most widespread type of green certified buildings in Italy. LEED building's energy and environmental certification system was developed by the U.S. Green Building Council (USGBC) in the 1990s. It is a tool for measuring the level of sustainability of buildings, neighborhoods, and cities in the design, construction, and management phases. LEED is a voluntary, market-oriented tool based on the consensus of the USGBC community. LEED certification proposes a measurement system (rating) applicable to buildings with different uses, both for existing and new assets. This is based on principles commonly recognized and accepted by the national scientific community $[10,15,16]$.

The LEED certification system is now adopted in 164 countries around the world with a significant presence in Italy, which can now count 544 buildings among the LEED certificates or those waiting to complete the procedure for more than 13.9 million square meters. In Italy, the level of sustainability achieved by the certification is high: the most used is the Gold, which records more than half of the existing buildings (56\%). This is followed by Platinum (19\%), while the lowest levels of certification reach low percentages (Certified 13\% of buildings and Silver 12\%). The types of real estate projects are concentrated on new constructions: $72 \%$ of certified buildings belong to the category "building design and construction", $11 \%$ concern retrofit operations on existing buildings while $17 \%$ certify "interior design and construction" interventions.

Based on the expectations that real estate markets and direct users have of a sustainable building, there is a great deal of empirical research that aims to verify how, and to what extent, environmental certification affects real estate values [15-18].

In particular, from an economic point of view, in the literature, the theme of sustainability in the built environment can be summarized in four macro-themes [17-21]. The first concerns the nature of investments in sustainable real estate development operations. For years, scientific research has aimed to assess whether, and to what extent, investments are repaid with the costs of potential energy savings [22-24].

Secondly, short- and medium-term benefits are investigated from the point of view of property occupants, such as savings on energy bill costs or possible tax breaks by governments [25-29]. Thirdly, from the point of view of developers and investors, possible benefits are investigated in relation to the increase in real estate value and the increase in rents, verifying whether these benefits can balance the higher costs of the interventions [28-31].

The fourth and last point, finally, aims to investigate the issue of the psycho-physical well-being of the occupants of sustainable buildings to verify the increase in well-being and productivity of workers [32-35].

Regarding the evaluation of the premium price of green buildings, which is one of the objectives of this research, Table 1 summarizes the results of various scientific studies that emerged from interviews (revealing the perception of relevant stakeholder) or empirical studies-in many countries that have led to different results. In Italy, despite that the sustainable construction is constantly increasing, an empirical research about the premium price of green buildings has not yet been carried out. 
Table 1. Summary of investigations in the international literature about the premium price—for rent and market value-in green buildings.

\begin{tabular}{|c|c|c|c|c|c|}
\hline Increased Market Value (\%) & Rental Premium (\%) & Type of Certificate & Data Origin & References & Country \\
\hline Average: 10.90 & Average: 6.10 & LEED & Perception & [5] & USA \\
\hline Average: 6.80 & Average: 1.00 & LEED & Perception & [28] & USA \\
\hline LEED: 9.94; Energy Star: 5.76 & Average: 8.93 & Energy Star & Empirical data & [29] & USA \\
\hline LEED: 16 & LEED: 3; Energy Star: 5 & Energy Star & Empirical data & [29] & USA \\
\hline \multirow{2}{*}{ LEED: 35; Energy Star: 31} & LEED: 6; Energy Star: 5 & LEED-Energy Star & Empirical data & [29] & USA \\
\hline & LEED: 17.30; Energy Star: 8.62 & Energy Star & Empirical data & [23] & USA \\
\hline \multirow[t]{3}{*}{ LEED: 9; Energy Star: 9} & & LEED-Energy Star & Empirical data & [36] & USA \\
\hline & Minimum: 4.71; maximum: 13.60 & -030 & Empirical data & [37] & Germany \\
\hline & Minimum: 3.97; maximum: 15.17 & - & Empirical data & [37] & Germany \\
\hline Minimum: 6.60; maximum: 15.90 & Minimum: 0.41 ; maximum: 5.87 & - & Empirical data & [37] & Switzerland \\
\hline Relative to D-labelled houses: A/B: 5; C: 1.7 ; E: -0.7 ; F: -0.9 ; G: -6.8 & & - & Empirical data & [38] & UK \\
\hline Average: 28 & & BREEAM & Empirical data & [39] & UK \\
\hline Average: 10 & Average: 6 & BREEAM & Empirical data & [7] & UK \\
\hline Relative to D-labelled houses: A: 9.3; B: 5.2; C: 1.7; E: 0; F/G: -10 & & & Empirical data & [40] & Ireland \\
\hline Relative to D-labelled houses: A: 10.2 ; B: 5.5 ; C: $2.1 ; \mathrm{E}:-0.5 ; \mathrm{F}:-2.3$; G: -4.8 & & & Empirical data & [41] & Netherlands \\
\hline Relative to D-labelled houses: A/B: 6.4; C: 6; E: -0.7 ; F: -12.3 ; G: -19.4 & & & Empirical data & [42] & Denmark \\
\hline Average: $10 \%$ & & & Perception & [11] & Italy \\
\hline
\end{tabular}




\section{The Market Investigated: Real Estate for Management Use in Milan}

In contrast to scientific research found in literature that analyzes a large dataset and provides a premium price nationwide, in Italy it is very difficult to have access to data on real estate transactions. Therefore, we have chosen to analyze a city that could be significant at the national level and could provide general real estate market trend.

The research was carried out in the city of Milan, the largest economic center in Italy and the most attractive location for international investors. According to CBRE, the stock of office buildings in Milan is made up of 12,000,000 square meters. Of these, in the last 12 months, the real estate market has absorbed 351,939 square meters while about 10\% (1.39 million square meters) is still waiting to be occupied. Most of these investments were concentrated in some specific areas. Focusing on the attractive locations for national and international investors, green new construction and renovation projects were examined in Porta Nuova and in the Central Business District (CBD).

Regarding the districts we examined, despite the crisis that hit the real estate sector from 2008, office properties showed signs of a countertrend. Market values of new (or in an excellent state of preservation) offices increased by $36 \%$ for the CBD area and by $110 \%$ for the Porta Nuova district, as shown in Table 2.

Table 2. The real estate market of properties for use in the tertiary sector in the CBD and Porta Nuova areas in Milan.

\begin{tabular}{cccccc}
\hline Neighborhood & Year & $\begin{array}{c}\text { Minimum } \\
\text { Real Estate } \\
\text { Market Value }\end{array}$ & $\begin{array}{c}\text { Maximum } \\
\text { Real Estate } \\
\text { Market Value }\end{array}$ & $\begin{array}{c}\text { Average } \\
\text { Market } \\
\text { Value }\end{array}$ & $\begin{array}{c}\text { Percentage of Increase } \\
\text { Compared to the } \\
\text { Average Value }\end{array}$ \\
\hline \multirow{2}{*}{ CBD } & 2018 & 6.700 & 9.200 & 7.950 & $+36 \%$ \\
& 2008 & 4.900 & 6.800 & 5.850 & $+110 \%$ \\
Porta Nuova & 2018 & 6.500 & 8.000 & 7.250 & 3.450 \\
\hline
\end{tabular}

Source: Agenzia delle Entrate.

The greatest contribution of Milan real estate developments has been concentrated in the two districts we examined. In particular, they host 458,323 square meters or $33 \%$ of the total amount of square meters developed in the city. Real estate developments can be divided in new buildings (132,672 square meters, $29 \%$ of the total) and in renovation projects, $(325,651$ square meters, $71 \%$ of the two districts).

Descriptive statistics of the 55 transactions of the sample are provided. Almost two thirds (64\%) of the transactions took place in the CBD area (35 cases) while $36 \%$ of the other transactions took place in the district of Porta Nuova (20 cases). Real estate developments reflect a general trend we found in Milan: $74 \%$ of the transactions concern refurbishments while $26 \%$ are new constructions. The size of the leased properties varies within the sample. Roughly a third ( $35 \%)$ of the assets (18 cases) have a surface area between 2000 and 5000 square meters while the upper size classes (between 5000 and 9999 square meters and between 10,000 and 24,999 square meters) are just over half of the sample. Finally, $10 \%$ of the sample refers to surfaces of more than 25,000 square meters, as shown in Figure 1 .

Properties of the sample hit the market over a period of time from 2009 to the present day. A fraction of the sample (7 properties) is still under development and is expected to be put on the market by 2020. The mode and the median of this sample coincide and are located at the center of the time period under examination (2014), as shown in Figure 2. 


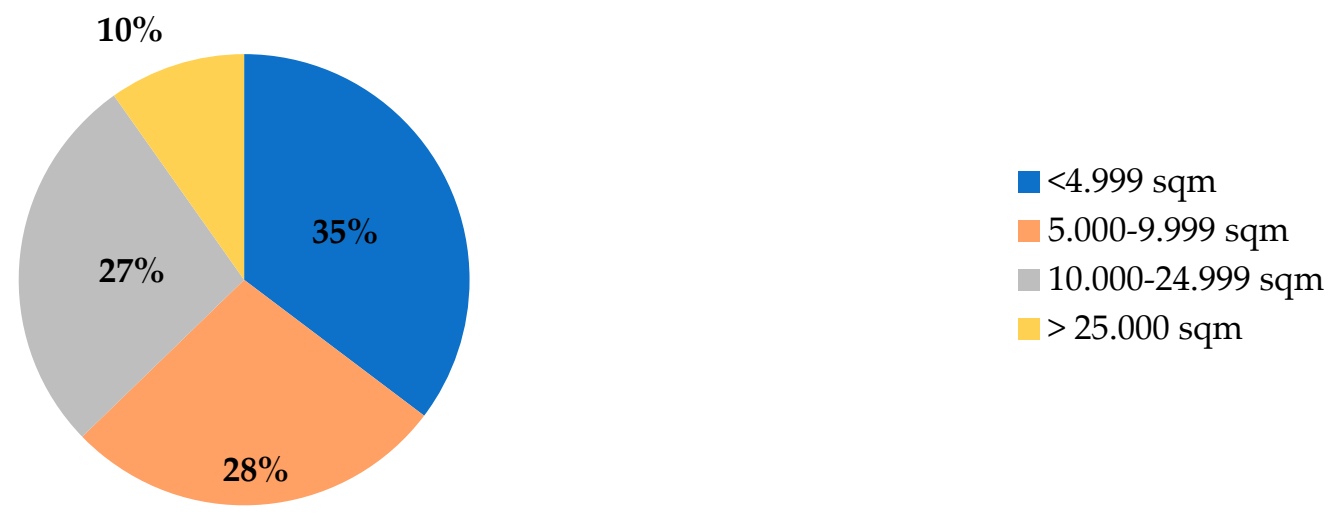

Figure 1. The size of the sample examined.

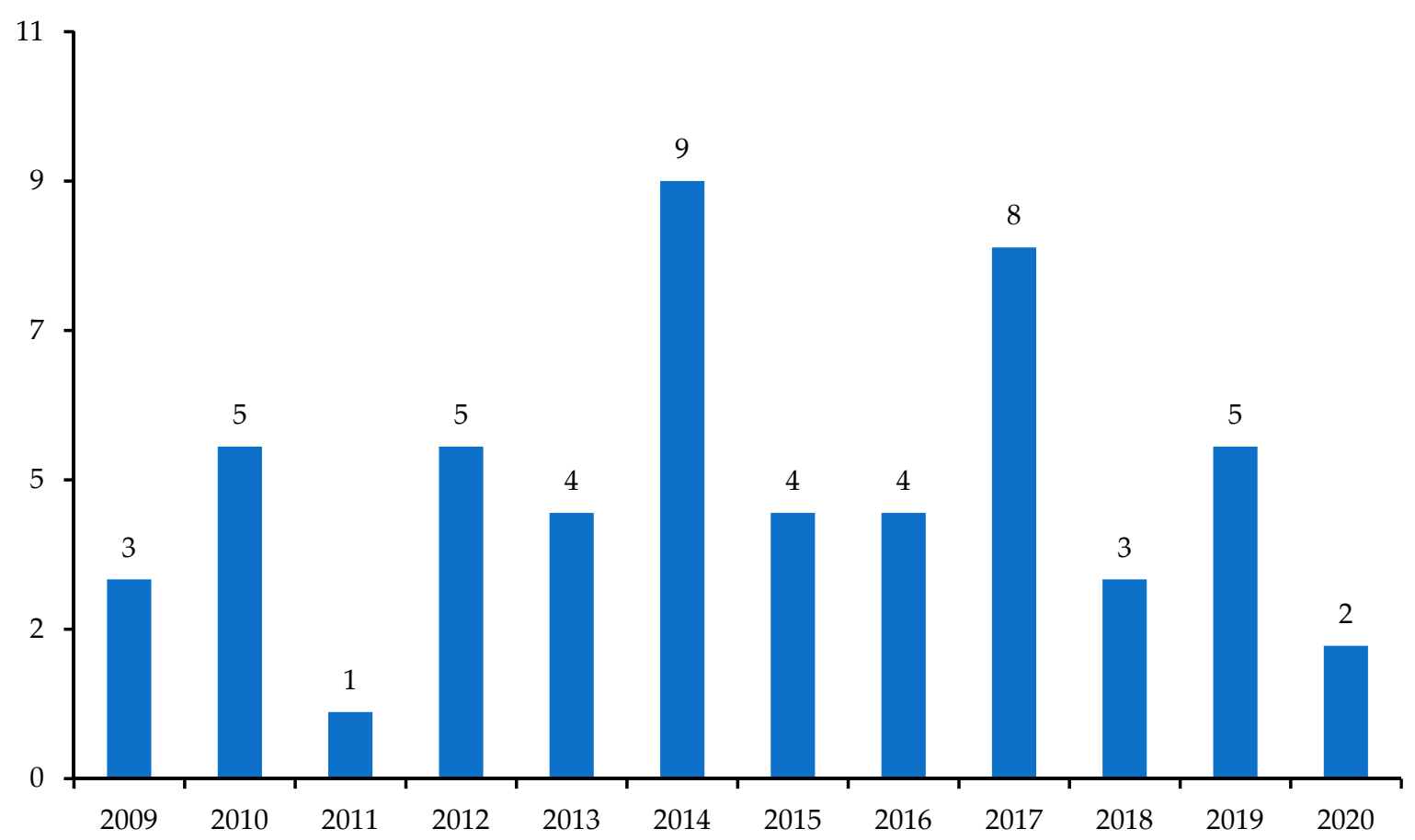

Figure 2. Year of placing on the market of the buildings examined.

The rental values are expressed in Euro/sqm/year and range from a minimum of 240 Euro/sqm/year to 560 Euro/sqm/year. The average sample amounts to 448 Euro/sqm/year while the median and fashion are equal to 450 Euro/sqm/year, as shown in the Figure below (Figure 3).

A fraction of the sample was awarded a LEED certificate, while the other properties were refurbished or constructed without any type of third-party formal acknowledgment. In particular, $55 \%$ of the assets surveyed have LEED certification (30 cases) while $45 \%$ are not certified ( 25 cases). The largest fraction of the sample gathers LEED Gold (36\%) buildings, while the LEED Silver and Platinum certificates concern a more limited amount of transactions ( $6 \%$ and $13 \%$ respectively), (see Figure 4). 


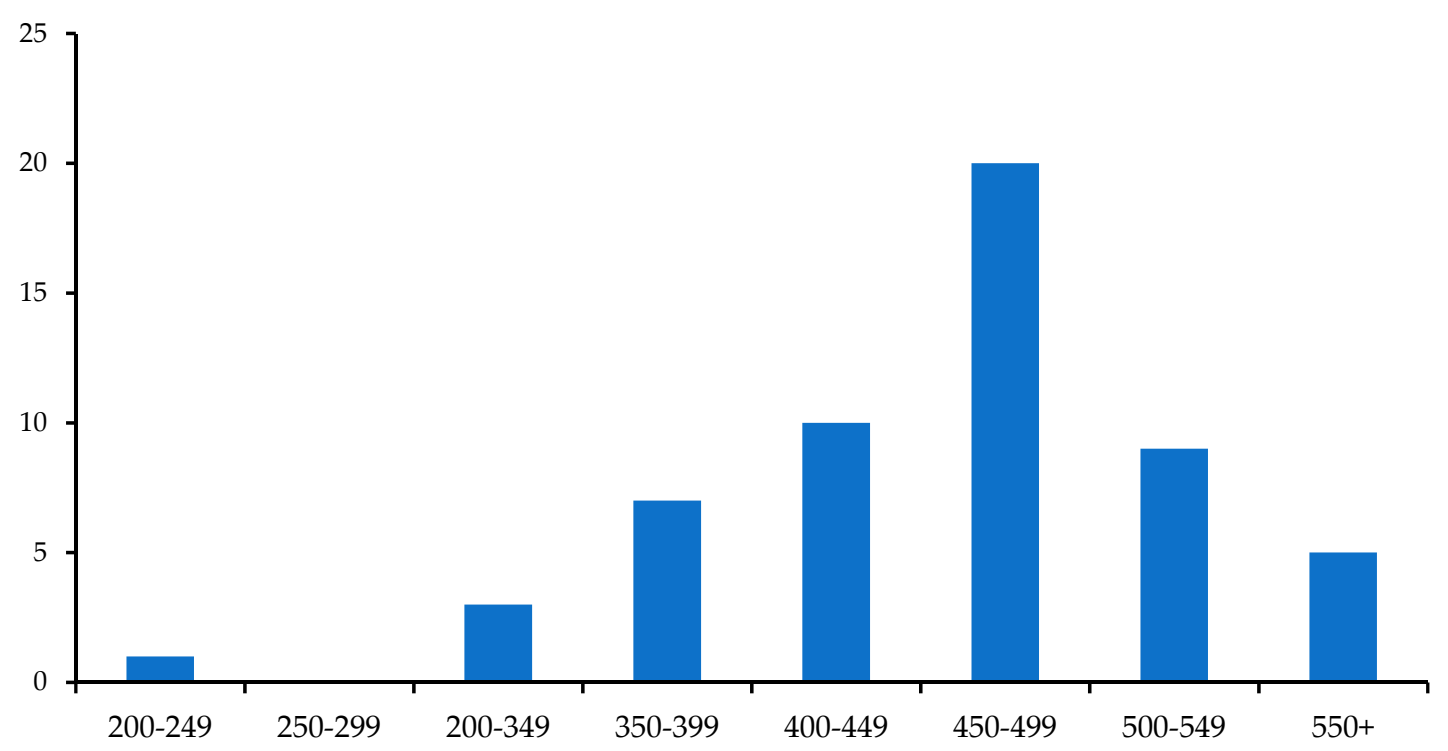

Figure 3. Rental fees expressed in Euro/sqm/year.

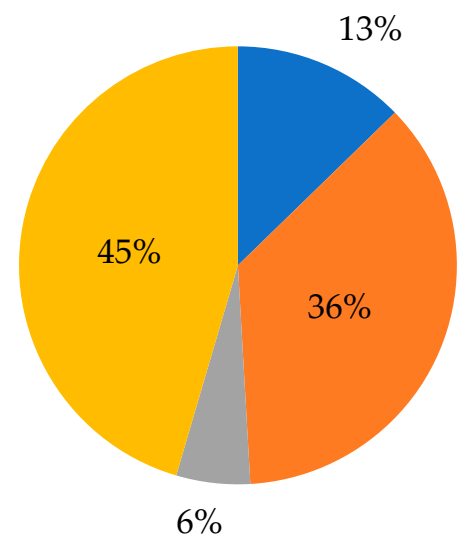

\author{
- LEED Platinum \\ LEED gold \\ - LEED silver \\ No LEED
}

Figure 4. LEED's certification level.

\title{
4. Hedonic Prices and Absorption Rates in Green Properties
}

The analysis of the present sample concerns two aspects of the market. The first one is related to the possible appreciation by the market for green assets compared to buildings that are not. In other words, we wanted to test if there is a premium price for LEED-certified assets compared to a comparable supply without any certification. The second aspect is linked to the time necessary to rent the assets. The hypothesis underlying the research is that green buildings not only obtain a premium price, but they are absorbed with faster timing. The first part of the investigation concerned the analysis of the hedonic prices of the characteristics recognized by the market. The second part of the research is the result of an in-depth analysis of a fraction of the dataset of which absorption time was known. Regarding the first step, multiple regression analysis was carried out. Real estate market values can be considered as a function of the prices of their characteristics. Regression models represent the instrument to break down the market prices into the hedonic prices of the relevant characteristics.

Functional forms can be different. Linear and non-linear regression models have been used in the study with analogous performance. Although the $\mathrm{R}^{2}$ is not particularly relevant, $p$-value of the hedonic prices of the characteristics proved to be significant (Table 3). 
Table 3. Results of the regression analysis.

\begin{tabular}{|c|c|c|c|c|}
\hline Summary & & & & \\
\hline R-squared & 0.183168 & & & \\
\hline Adjusted $\mathrm{R}^{2}$ & 0.151751 & & & \\
\hline Standard deviation & 59.30195 & & & \\
\hline Observations & 55 & & & \\
\hline \multicolumn{5}{|l|}{ Variance analysis } \\
\hline & DF & Sum of squares & Mean square & F ratio \\
\hline Model & 3 & $41,035.90$ & $20,503.5$ & 5.8303 \\
\hline Error & 52 & $182,859.53$ & 3515.7 & Prob $>$ F \\
\hline C.total & 54 & $223,878.44$ & & 0.0552 \\
\hline \multicolumn{5}{|l|}{ Parameters evaluation } \\
\hline & Evaluation & ST. Error & T ratio & \\
\hline Intercept & 412.95182 & 12.9596 & 31.94 & $<0.0001$ \\
\hline Submarket & 44.020393 & 18.52337 & 2.85 & 0.0107 \\
\hline Type of certification & 15.285029 & 7.012145 & 2.18 & 0.0338 \\
\hline
\end{tabular}

The two hedonic prices-relating to the location of buildings and the type of LEED certification - define the market value of these two variables. LEED certification rewards properties according to their performance: the premium price for the position in the traditional CBD amounts to $44 \mathrm{Euro} / \mathrm{sqm} / \mathrm{year}$, while the hedonic price related to the type of certification amounts to 15 Euro/sqm/year (see Table 4 and Figure 5). The model shows that the increase in the hedonic price related to the building's environmental quality amounts to $3.69 \%$ for each step of the LEED certification. The Silver level does not prove to be statistically significant because of the limited amount of transactions. With a Gold certification, the market value increase amounts to $7.38 \%$, while the Platinum level determines an increase of $11.08 \%$.

The regression analysis shows a statistically significant premium price for the location of the assets and for the type of certification. In particular, location in the CBD area implies a premium price estimated in $11 \%$ compared to the average. With respect to LEED certification, the market considers the Gold certification - with a premium of $7.4 \%$-and the Platinum one with a further positive variation of more than $11 \%$, as shown in the following table.

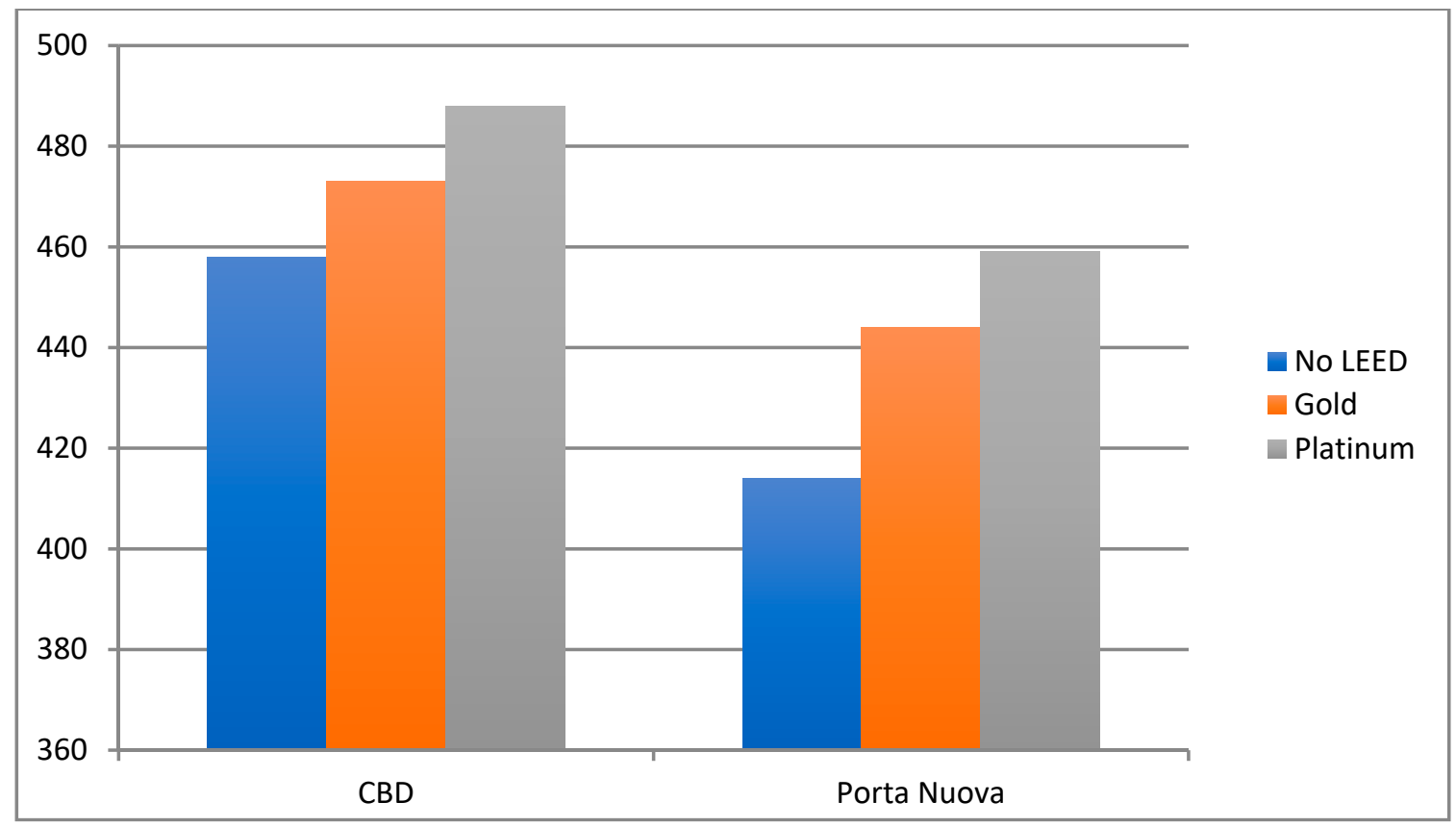

Figure 5. Implied marginal prices based on positional quality and certification level. 
Table 4. Implied marginal prices based on positional quality and certification level.

\begin{tabular}{ccccc}
\hline Market Rent & Neighborhood & Price (+44 Euro) & Type of Certificate & Price +15 Euro \\
\hline \multirow{3}{*}{414} & CBD $+11 \%$ & 458 & None $0 \%$ & 458 \\
& & & Gold $+7.38 \%$ & 488 \\
& & & Platinum $+11.08 \%$ & 503 \\
& Porta Nuova $+0 \%$ & None $0 \%$ & 414 \\
& & & Gold $+7.38 \%$ & 444 \\
& & & Platinum $+11.08 \%$ & 459 \\
\hline
\end{tabular}

The second part of the survey refers to a subsample of the transactions whose absorption times are known. Twenty-five transactions were examined. The descriptive statistics of this subset are consistent with those of to the complete dataset. In particular, $56 \%$ of the case studies are in the CBD area while the remainder are located near Porta Nuova. The $84 \%$ of the cases are renovation projects while $16 \%$ are new constructions. The average surface area is $8232 \mathrm{sqm}$, with a total analyzed surface area of 205,804 square meters, dived as follows: 134,438 sqm of LEED buildings and 71,366 sqm of non-certified buildings. The projects' year of completion starts in 2009. The average and the median coincide in 2014. 15 transactions refer to LEED-certified buildings (nine Gold and six Platinum).

Data concerning this subsample allowed to investigate the absorption times of each building. The rentals recorded on a quarterly basis up to 30 months were examined and the actual leased surface area was measured. The analysis of relative and absolute frequencies revealed a clear preference for certified buildings. As shown in Figures 6 and 7, the 51\%, of the surface area of certified buildings is already pre-let. Within six months of the completion of the intervention, the leased areas amount about to $80 \%$ of the available supply. After two and a half years from the placing on the market, the vacancy rate amounts to a percentage of about $7 \%$.

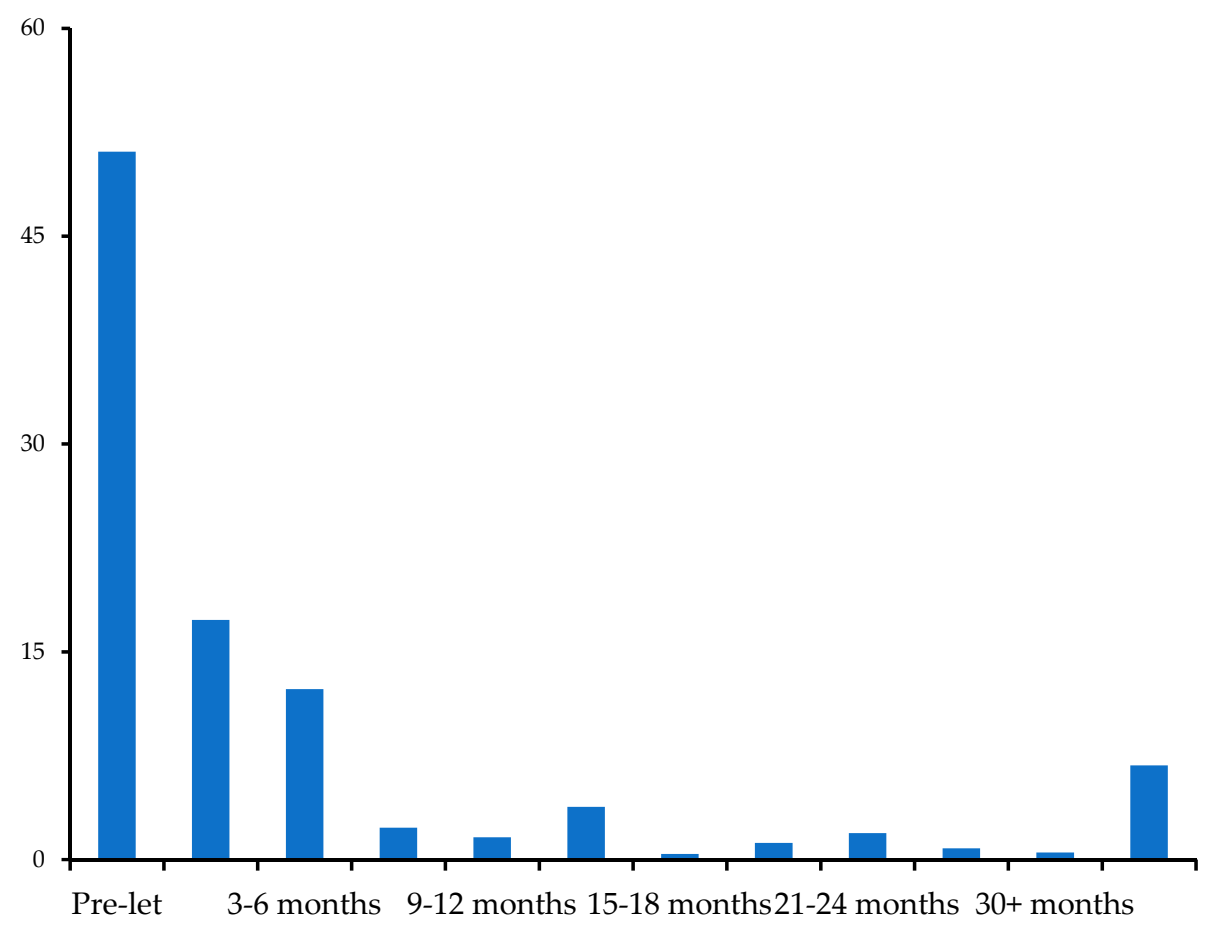

Figure 6. Analysis of the absolute frequencies of absorption times in LEED-certified buildings. 


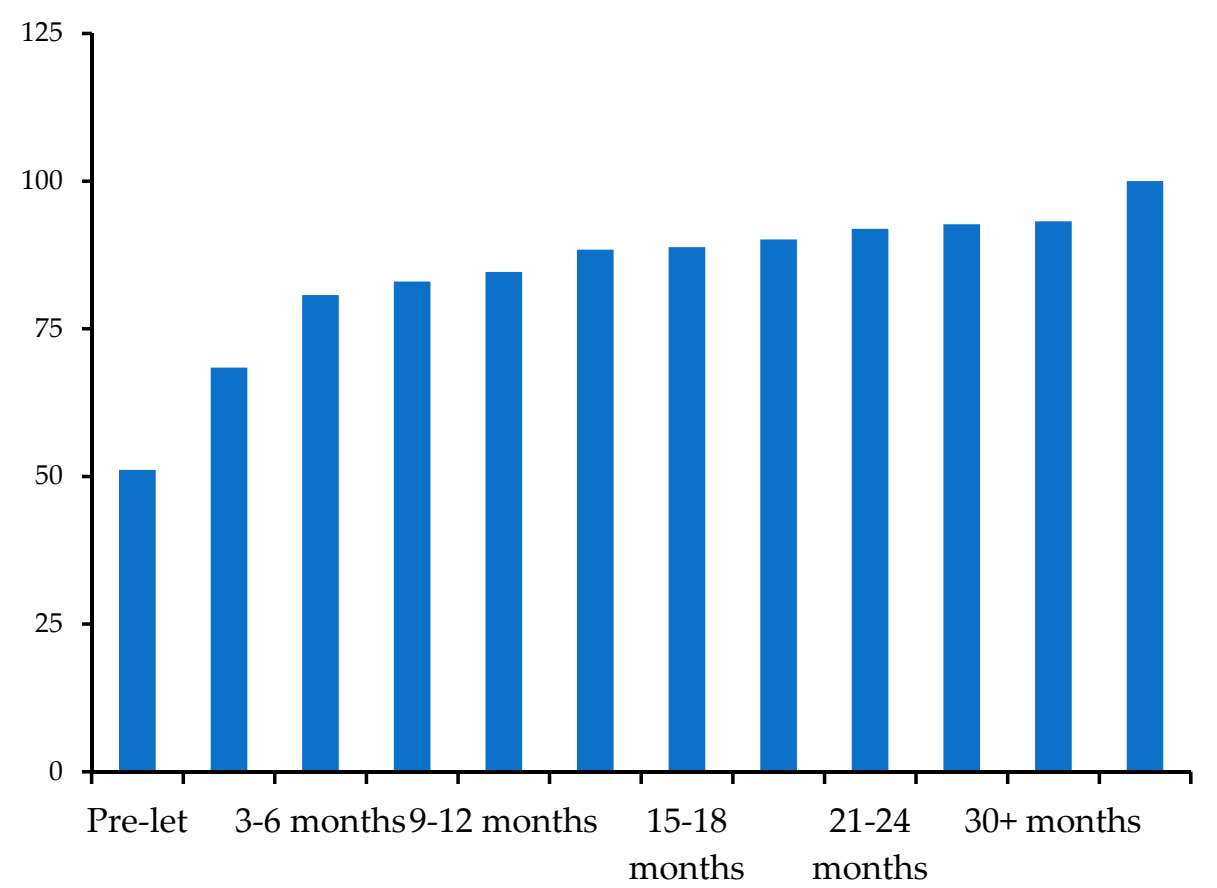

Figure 7. Analysis of the relative frequencies of absorption times in LEED-certified buildings.

Regarding non-certified buildings, pre-let leases amount to only $13 \%$. After six months, leased areas amount to $21 \%$ of the total supply. After two years and a half, the vacancy rate amounts to more than $14 \%$ (see Figures 8 and 9).

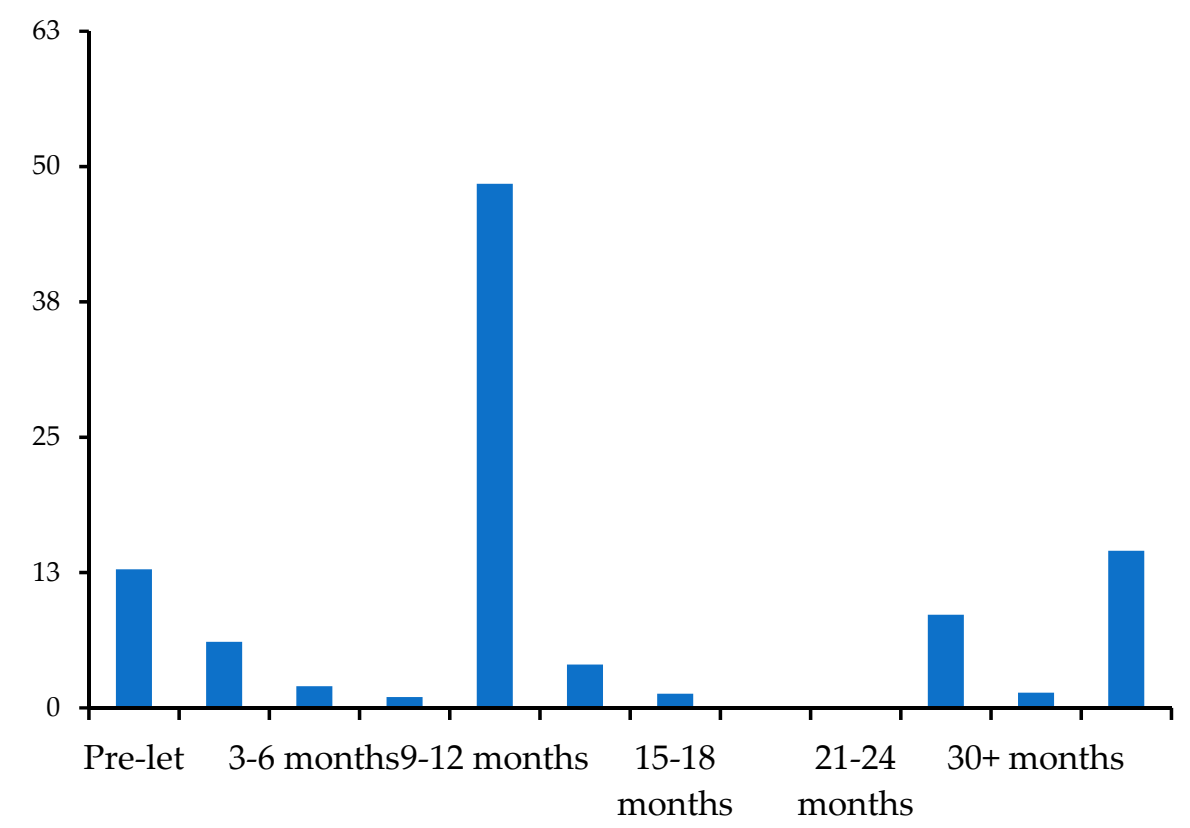

Figure 8. Analysis of the absolute frequencies of absorption times no certified buildings. 


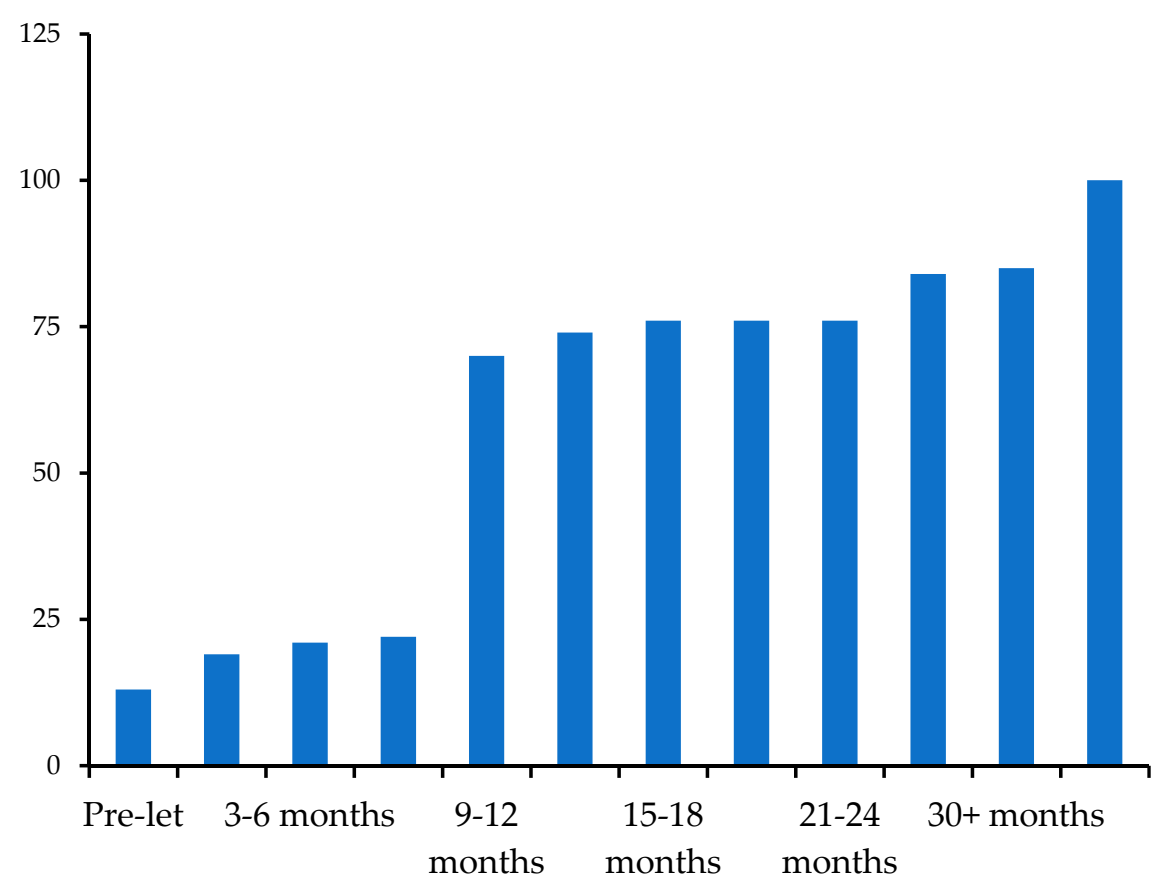

Figure 9. Analysis of the relative frequencies of absorption times no certified buildings.

\section{Sustainability Turns into Value: Survey Results}

The investigations carried out in the two previous figures have revealed three significant elements. Developers and building owners aim to achieve a high level of certification to increase the buildings market attractiveness [35]. Recent research has shown that developers are interested in the most qualifying level of certification. Developers seem to be interested in presenting to the market a supply with a clear market distinction and therefore seem to prefer the most qualified levels of certification $[25,26,35]$.

As GBCI pointed out, with a higher construction cost of about $3-4 \%$ for the first two levels of LEED certification and about $5-7 \%$ for the Gold and Platinum levels, better certifications show higher returns on investment and lower operating costs over the life of the property. No coincidence that more than 20 buildings of the sample have Gold certification compared to only three buildings certified Silver.

Second, there is a significant premium price for properties certified at the highest levels (Gold and Platinum) with price differentials of $7 \%$ and $11 \%$ respectively. These percentages are in line with studies emerging from other research, as shown in Table 1 . The variation of the results emerged depends on the use of a different sample, located in different places with various characteristics and on the use of different methods of analysis. The common result is that green buildings benefit of a significant increase in market value and provide benefits to the community and to the environment $[10,11,38]$.

Third, a more in-depth investigation of certified asset absorption rates reflects market preferences for certified properties. Absorption rates are four times higher for the pre-let segment. Within six months the percentage leased is $80 \%$ for certified properties and $21 \%$ for non-certified properties.

Both elements contribute to guarantee higher financial performance of certified green investments due to the increase in revenue values and their more economically favorable timing. Faster absorption times and a higher premium price compared to non-certified buildings can positively influence the internal rate of return of the development investments. In recent years, green buildings have become a dominant part of the tertiary supply. Real estate values and rents reflect this trend, showing that the particular appreciation of the market for LEED-certified buildings is a structural aspect of this specific segment of the market. This has significant implications for investors, developers, and government policies [36-44]. 
Non-certified office buildings are likely to suffer a market downturn. Research results have shown that developers attribute lower premium risk to more sustainable buildings. Increased market awareness of climate change and rising energy costs can only increase the market attractiveness of green buildings. The research also highlights the potential of policies that provide incentives for green buildings as they increase the value of buildings and at the same can influence buildings energy efficiency and their environmental impact [11].

\section{Conclusions}

In the broad area of research concerning a more sustainable built environment, it seems of the utmost importance that demand considers green buildings as a valuable solution, so transforming a potential constraint into a business opportunity. For this reason, we decided to test whether, and to what extent, green buildings could achieve a higher price and an overall superior economic performance than traditional real estate supply. The dataset concerned the real estate market of Milan, the leading market of the industry in Italy and the location in which the interaction between national and international investors provides the best evidence concerning future trends.

The investigation carried out confirms the results of empirical research in other countries, suggesting that sustainability will become a significant value driver in the future. The premium price of the LEED certified buildings is statistically significant and appears to be higher as the level of certification increases. Similarly, the rate of absorption of certified assets reflects a significant preference for green properties. Both aspects investigated contribute to define higher financial performance of green investments due to the combined effect of the increase in revenue values and their more favorable temporal articulation.

Future researches may concern more precisely the variation of the IRR related to sustainable and green real estate developments, putting into evidence to what extent additional financial value can be obtained by a green strategy. Furthermore, it seems very relevant to verify if the importance of sustainability in the real estate market remains the prerogative of a limited fraction of the market itself or expands into other geographical areas and other market segments. Finally, it appears to be important to understand if traditional supply, in specific segments or in the overall market, is going to be downgraded by the market accelerating the transition of the real estate industry into a new phase in which sustainability is a common and widespread driver of value.

Author Contributions: Conceptualization, E.M.; Data curation, A.M. and F.S.; Formal analysis, A.M. and E.M.; Methodology, E.M.; Supervision, E.M.; Writing-original draft, A.M., writing-review and editing, A.M. and E.M.

Funding: This research was funded by Ministero dell'Istruzione, dell'Università e della Ricerca, grant number PRIN 2015 protocol 2015STFWFJ_004.

Acknowledgments: We are grateful to CBRE for the dataset provided.

Conflicts of Interest: The authors declare no conflict of interest.

\section{References}

1. IPCC. Global Warming of 1.5 C. 2018. Available online: http://www.ipcc.ch/report/sr15/ (accessed on 13 November 1988).

2. RICS. Supply, Demand and the Value of Green Buildings. Rics Research. 2012. Available online: http://www.breeam.es/images/recursos/inf/informe_rics_supply_demand_and_the_value_of_ green_buildings.pdf (accessed on 21 October 2018).

3. Micelli, E.; Mangialardo, A. Recycling the City-New Perspective on the Real-estate Market and Construction Industry. In Smart and Sustainable Planning for Cities and Regions; Bisello, A., Vettorato, D., Stephens, R., Elisei, P., Eds.; Springer: Cham, Switzerland, 2015; pp. 115-125.

4. Brown, D.; Dillard, J.; Marshall, R.S. Triple Bottom Line: A Business Metaphor for a Social Construct; School of Business Administration, Portland State University: Portland, OR, USA, 2006.

5. McGraw Hill Construction. Green Building Smart Report; McGraw Hill: Bedford, UK, 2008. 
6. Fuerst, F.; Mcallister, P. Green Noise or Green Value? Measuring the Price Effects of Environmental Certification in Commercial Buildings; School of Real Estate and Planning, Henley Business School, University of Reading: Reading, MA, USA, 2008.

7. Fuerst, F.; Mcallister, P. Pricing sustainability: An empirical investigation of the value impacts of green building certification. In Proceedings of the American Real Estate Society Conference, Captiva Island, FL, USA, 10-14 April 2008.

8. Attardi, R.; Cerreta, M.; Sannicandro, V.; Torre, C.M. Non-compensatory composite indicators for the evaluation of urban planning policy: The Land-Use Policy Efficiency Index. Eur. J. Oper. Res. 2018, 264, 491-507. [CrossRef]

9. Boyd, T.; Kimmet, P. The Triple Bottom Line Approach to Property Performance Evaluation; School of Construction Management and Property, Queensland University of Technology: Brisbane, Australia, 2006.

10. Fedrizzi, R.S.; Morri, G.; Pavesi, A.S.; Soffietti, F.; Verani, E. Uno strumento per la creazione di valore nella realizzazione di edifici sostenibili: La certificazione LEED. Territorio Italia 2016, 2, 37-47. [CrossRef]

11. Morri, G. Greenbuilding sustainability and market premium in Italy. J. Eur. Real-Estate Res. 2013, 6, $303-332$. [CrossRef]

12. Matisoff, D.C.; Noonan, D.S.; Mazzolini, A.M. Performance or market benefits? The case of LEED certification. Environ. Sci. Technol. 2014, 48, 2001-2007. [CrossRef] [PubMed]

13. Energy and Sustainability. Available online: https://www.cbre.it/it-it/servizi/settori/energy-and-sustainability (accessed on 13 November 2018).

14. Documenti e Risorse. Available online: http:/ / www.gbcitalia.org (accessed on 13 November 2018).

15. Chappell, T.W.; Corps, C. High Performance Green Building: What's It Worth? Investigating the Market Value of High Performance Green Buildings; Cascadia Region Green Building Council: Seattle, WA, USA, 2010.

16. Pavesi, A.S.; Verani, E. Introduzione Alla Certificazione LEED®: Progetto, Costruzione, Gestione-Ottimizzazione del Processo Edilizio Secondo i Principi Della Sostenibilità; Maggioli Editore: Rimini, Italy, 2012.

17. Chegut, A.; Eicholtz, P.; Kok, N. The Value of Green Buildings-New Evidence from the United Kingdom. Available online: http://immobilierdurable.eu/images/2128_uploads/Chegut_Eichholtz_Kok_green_ value_in_the_uk.pdf (accessed on 13 November 2018).

18. Robinson, S.; McAllister, P. Heterogeneous Price Premiums in Sustainable Real Estate? An Investigation of the Relation between Value and Price Premiums. Joisre 2015, 1, 1-20.

19. Antoniucci, V.; Marella, G. The influence of building tipology on the economic feasibilityof urban developments. Int. J. Appl. Eng. Res. 2018, 15, 4946-4954.

20. Antoniucci, V.; Marella, G. Is social polarization related to urban density? Evidence from the Italian housing market. Landsc. Urban Plan. 2018, 177, 340-349. [CrossRef]

21. Del Giudice, V.; Salvo, F.; DE Paola, P. Resampling Techniques for Real Estate Appraisals: Testing the Bootstrap Approach. Sustainability 2018, 10, 3085. [CrossRef]

22. Warren-Myers, G. The value of sustainability in real estate: A review from a valuation Perspective. J. Prop. Invest. Financ. 2012, 30, 115-144. [CrossRef]

23. Mangialardo, A.; Micelli, E. Rethinking the Construction Industry Under the Circular Economy: Principles and Case Studies. In Smart and Sustainable Planning for Cities and Regions; Bisello, A., Vettorato, D., Laconte, P., Costa, S., Eds.; Springer: Cham, Switzerland, 2018.

24. Fuerst, F.; McAllister, P. New evidence on the green building rent and price premium. In Proceedings of the Annual Meeting of the American Real Estate Society, Monterey, CA, USA, 3 April 2009.

25. Entrop, A.G.; Brouwers, H.J.H.; Reinders, A.H.M.E. Evaluation of energy performance indicators and financial aspects of energy saving techniques in residential real estate. Energy Build. 2010, 42, 618-629. [CrossRef]

26. D'Alpaos, C.; Bragolusi, P. Approcci valutativi alla riqualificazione energetica degli edifici: Stato dell'arte e future sviluppi. Valori e Valutazioni 2018, 20, 1-15.

27. Altomonte, S.; Schiavon, S. Occupant satisfaction in LEED and non-LEED certified buildings. Build. Environ. 2013, 68, 66-76. [CrossRef]

28. Mangialardo, A.; Micelli, E. Off-site Retrofit to Regenerate Multi-family Homes: Evidence from Some European Experiences. In International Symposium on New Metropolitan Perspectives; Calabrò, F., Della Spina, L., Bevilacqua, C., Eds.; Springer: Cham, Switzerland, 2018.

29. McGraw Hill Construction. Green Building Smart Report; McGraw Hill: Bedford, UK, 2009. 
30. Warren-Myers, G.; Reed, R. Sustainability: Measurement and valuation?-Insight from Australia and New Zealand. In Proceedings of the 15th Annual Pacific Rim Real Estate Society Conference, Sydney, Australia, 18-21 January 2009.

31. Zieba, M.; Belniak, S.; Gluszak, M. Demand for sustainable Office space in Poland: The results from a conjoint experiment in Krakow. Prop. Manag. 2013, 31, 404-419. [CrossRef]

32. Gabe, J.; Rehm, M. Do tenants pay energy efficiency rent premiums? J. Prop. Invest. Financ. 2014, 32, $333-351$. [CrossRef]

33. Pivo, G.; Fisher, J.D. Investment Returns from Responsible Property Investments: Energy Efficient, Transit-Orientated and Urban Regeneration Office Properties in the US from 1998-2008; Working Paper; Responsible Property Investing Center, Boston College and University of Arizona Benecki Center for Real Estate Studies, Indian University: Boston, MA, USA, 2009.

34. Forte, F.; Russo, Y. Evaluation of users satisfaction in public residential housing-A study in the outskirtsof Naples, Italy. In IOP Conference Series: Materials Science and Engineering; IOP Publishing: Bristol, UK, 2017; Volume 245, pp. 52-63.

35. Fuerst, F.; McAllister, P. Green noise or green value? Measuring the effects of environmental certification on office value. Real Estate Econ. 2011, 39, 45-69. [CrossRef]

36. Kok, N.; Kahn, M.E. The Value of Green Labels in the California Housing Market, 2012, UCLA Institute of the Environment and Sustainability. Available online: http:/ /www.environ-ment.ucla.edu/newsroom/thevalue-of-green-la-bels-in-the-california-housing-market/ (accessed on 13 November 2018).

37. Bienert, S.; Schuzenhofer, C.; Leopoldberger, G.; Bobsin, K.; Leugtob, K.; Huttler, W.; Popescu, D.; Mladin, E.C.; Iasi, T.; Rodica, B.; et al. Integration of Energy Performance and life-Cicle Costing into Property Valuation Practice, 2011. Report Summary. Available online: http:/ /immovalue.e-sieben.at/pdf/ immvalue_result_oriented_report.pdf (accessed on 13 November 2018).

38. Meins, E.; Burkhard, H.-P. Der Nachhaltigkeit von Immobilien Einen Finanziellen Wert Geben; ESI Immobilienbewertung-Nachhaltigkeit inclusive: Zürich, Switzerland, 2009.

39. RICS. Supply, Demand and the Value of Green Buildings. Available online: https://www.isurv. com/downloads/download/1492/supply_demand_and_the_value_of_green_buildings_rics (accessed on 13 November 2018).

40. Hyland, M.; Lyons, R.C.; Lyons, S. The value of domestic building energy efficiency-Evidence from Ireland. Energy Econ. 2012, 40, 943-952. [CrossRef]

41. Brounen, D. Kok, N. On the economics of energy labels in the housing market. J. Environ. Econo. Manag. 2011, 62, 166-179. [CrossRef]

42. SBi. Cost-optimal Levels of Minimum Energy Performance Requirements in the Danish Building Regulations. Available online: https:/ / sbi.dk/Pages/Cost-optimal-levels-of-minimum-energy-performance-requirementsin-the-Danish-Building-Regulations.aspx (accessed on 13 November 2018).

43. Popescu, D.; Bienert, S.; Schutzenhofer, C.; Bozau, R. Impact of energy efficiency measures on the economic value of buildings. Appl. Energy 2012, 89, 454-463. [CrossRef]

44. Audanaert, A.; De Boeck, L.; Roelants, K. Economic analysis of the profitability of energy-Saving architectural measures for the achievement of the EPBD standard. Energy 2010, 35, 2965-2971. [CrossRef]

(C) 2018 by the authors. Licensee MDPI, Basel, Switzerland. This article is an open access article distributed under the terms and conditions of the Creative Commons Attribution (CC BY) license (http://creativecommons.org/licenses/by/4.0/). 